\title{
On triatomines, cockroaches and haemolymphagy under laboratory conditions: new discoveries
}

\author{
Pamela Durán1, Edda Siñani², Stéphanie Depickère ${ }^{2,3 /+}$ \\ ${ }^{1}$ Universidad Mayor de San Andrés, Instituto de Investigación en Salud y Desarrollo, Cátedra de Parasitología, La Paz, Bolivia \\ ${ }^{2}$ Instituto Nacional de Laboratorios de Salud, Laboratorio de Entomología Médica, La Paz, Bolivia \\ ${ }^{3}$ Institut de Recherche pour le Développement, Embajada Francia, La Paz, Plurinational State of Bolivia
}

For a long time, haematophagy was considered an obligate condition for triatomines (Hemiptera: Reduviidae) to complete their life cycle. Today, the ability to use haemolymphagy is suggested to represent an important survival strategy for some species, especially those in genus Belminus. As Eratyrus mucronatus and Triatoma boliviana are found with cockroaches in the Blaberinae subfamily in Bolivia, their developmental cycle from egg to adult under a "cockroach diet" was studied. The results suggested that having only cockroach haemolymph as a food source compromised development cycle completion in both species. Compared to a "mouse diet", the cockroach diet increased: (i) the mortality at each nymphal instar; (ii) the number of feedings needed to molt; (iii) the volume of the maximum food intake; and (iv) the time needed to molt. In conclusion, haemolymph could effectively support survival in the field in both species. Nevertheless, under laboratory conditions, the use of haemolymphagy as a survival strategy in the first developmental stages of these species was not supported, as their mortality was very high. Finally, when Triatoma infestans, Rhodnius stali and Panstrongylus rufotuberculatus species were reared on a cockroach diet under similar conditions, all died rather than feeding on cockroaches. These results are discussed in the context of the ecology of each species.

Key words: Triatominae - haemolymphagy - survival - fecundity - life cycle - Bolivia

Triatomines (Hemiptera: Reduviidae) are also known as kissing bugs. Approximately 150 species have been described; all of them are haematophagous and considered as potential vectors of Trypanosoma cruzi (Kinetoplastida: Trypanosomatidae), the aetiological agent of Chagas disease or American trypanosomiasis (Telleria \& Tibayrenc 2010, Justi et al. 2014). Chagas disease is endemic to the Americas and represents a major sanitation issue in Central and South America (WHO 2010). Most triatomine species are sylvatic and feed on small terrestrial and arboreal mammals, especially didelphids, edentates, and rodents, or live in association with bats or birds. Only a few species have colonised human dwellings, where they can transmit the T. cruzi parasite to humans and domestic mammals (Lent \& Wygodzinsky 1979, Carcavallo et al. 1998, Telleria \& Tibayrenc 2010).

Although feeding on invertebrates has been observed in some species (Brumpt 1914, Ryckman 1951, Miles et al. 1981), haematophagy was historically considered an obligate condition for triatomines to complete their life cycle (Lent \& Wygodzinsky 1979). Haematophagy is the most common feeding practice in the triatomine subfamily; nevertheless, three other practices have been described: cleptohaematophagy, or feeding on the ingested blood meal of another triatomine; haemolymphagy, or feeding on arthropod haemolymph (Sandoval et al.

doi: 10.1590/0074-02760160027

+ Corresponding author: stephanie.depickere@gmail.com

Received 26 January 2016

Accepted 19 July 2016
2010); and phytophagy, or feeding on sugar meal, which was recently demonstrated (Díaz-Albiter et al. 2016). In haemolymphagy, three different behaviours can be distinguished: intraspecific haemolymphagy (also called cannibalism by some authors and defined as a feeding on the haemolymph from individuals of the same species); intrasubfamily haemolymphagy (also called 'ectoparasite' cannibalism and defined as feeding from an individual of another Triatominae species); and extrasubfamily haemolymphagy, defined as feeding on haemolymph from a non-triatomine invertebrate (Sandoval et al. 2010).

With the increase in the literature regarding the feeding sources of triatomines over the last 30 years, haemolymphagy has been observed in more than 20 species belonging to the genera Belminus (Lent \& Wygodzinsky 1979, Sandoval et al. 2000, 2004, 2010, 2013), Eratyrus (Miles et al. 1981), Psammolestes (Carcavallo et al. 1998, Noireau et al. 2005a), Panstrongylus (Carcavallo et al. 1998, Garrouste 2009), Rhodnius (Brumpt 1914, Marinkelle 1965, Piñero et al. 1988) and Triatoma (Brumpt 1914, Ryckman 1951, Phillips 1960, Lent \& Wygodzinsky 1979, Salvatella \& Calegari 1991, Salvatella et al. 1994, Lorosa et al. 2000, Ruas-Neto et al. 2001, Vezzani et al. 2001, Emmanuelle-Machado et al. 2002, Freitas et al. 2005, Noireau et al. 2005a, Silva et al. 2005, Zeledón et al. 2010, Alves et al. 2011, Pontes et al. 2011, Cardozode-Almeida et al. 2014). The ability to use haemolymphagy is suggested to represent an important survival strategy under natural conditions for some species, resulting in optimised use of available nutrition resources and an increase in the probability of survival when vertebrate hosts are absent (Salvatella et al. 1994, Lorosa et al. 2000, Ruas-Neto et al. 2001, Alves et al. 2011). Complete 
egg-to-adult development seems to be seriously compromised by a diet of haemolymph alone, except in species within the genus Belminus, in which haemolymphagy seems to predominate and vertebrate blood is an infrequent food source (Sandoval et al. 2010, 2013).

In Bolivia, two species of triatomines found inside and/or around human dwellings, Eratyrus mucronatus and Triatoma boliviana, were also frequently found in the presence of large cockroaches of the Blaberus sp. (8 $\mathrm{cm}$ long for adults) in the subfamily Blaberinae (Martínez et al. 2007, Depickère et al. 2012, Durán et al. 2014). Interestingly, both species naturally demonstrate a null or weak level of infection by $T$. cruzi [proportion of infected insects: E. mucronatus: $0 \%$ by microscopical observation of 68 faeces (Noireau et al. 1995); 19.1\% by polymerase chain reaction (PCR) test of 68 faeces (Noireau et al. 1995); 0\% by microscopical observation of 75 faeces (Depickère et al. 2012); T. boliviana: 0\% by microscopical observation of 325 faeces (Depickère, pers. comm.)]. E. mucronatus is found in dwellings in a region of the Department of La Paz, in Bolivia (Depickère et al. 2012). Colonies of this species were observed in the boundary walls of peridomiciles constructed of tapial, or rammed earth. The tops of these walls were covered by branches and earth and accommodated triatomines, cockroaches, and other invertebrates. Haemolymphagy on spiders has been previously described in this species (Miles et al. 1981). In the laboratory, they feed readily on hens and mice. T. boliviana is found in another region of the Department of La Paz in stone walls delimiting fields (Martínez et al. 2007, Durán et al. 2014). Little is known about their natural food sources. In the laboratory, they will feed on mice, but not on hens.

A laboratory study was performed to verify whether these two species were able to feed on the haemolymph of cockroach species found within their capture zones and complete their life cycle with only this food source. Other triatomine species found in Bolivia (Triatoma infestans, Rhodnius stali and Panstrongylus rufotuberculatus) were also provided the same "cockroach diet" as a preliminary investigation of their ability to exploit this food source, though there have not yet been any reports indicating that these species live in association with cockroaches.

\section{MATERIALS AND METHODS}

Species were reared under controlled laboratory conditions: E. mucronatus (captured in Province of Franz Tamayo, La Paz), T. infestans (Province of Oropeza, Chuquisaca), P. rufotuberculatus (Province of Muñecas, La Paz) and $R$. stali (Province of Sud Yungas, La Paz) were kept under $26 \pm 2^{\circ} \mathrm{C}$ and $60 \pm 10 \% \mathrm{RH} ;$ T. boliviana (Province of Muñecas, La Paz) was kept under $22 \pm 2{ }^{\circ} \mathrm{C}$ and $60 \pm 10 \% \mathrm{RH}$. The dark:light cycle was 12:12 for all species. The study began with first instar nymphs (N1) from the first generation (F1) as soon as they hatched. The development of the cohort was followed through the nymphal instar and adult stages until death. Each nymph was reared individually. Adults were reared in pairs to observe fecundity and then egg viability. Insects had the opportunity to feed for two hours, twice a week. Two hours has been observed as an adequate duration of feeding ad libitum for triatomines. The food intake was determined by the increase in weight, as measured on a precision balance (Precisa Instrument Switzerland, XT220A). The life-time, mortality rate and number of feedings were recorded for each instar. The results were compared with those obtained in the same conditions but using a mouse as the food source. Due to the small number of individuals, data were analysed with non-parametric tests (Mann-Whitney U test, Kruskal-Wallis test, Chi-squared test and Fisher Exact test) using R (R team).

Diet - Blaberus sp. cockroaches (Blattodea: Blaberidae: Blaberinae, Philippe Grandcolas, MNHN Paris, pers. com.) were captured at the same time as the triatomines. Cockroaches were reared under laboratory conditions and supplied with food (laboratory rodent food) and water ad libitum. A total of 37 N1 E. mucronatus and $351 \mathrm{~N} 1$ T. boliviana were used in the study. Nymphs of E. mucronatus were fed only on cockroaches until their death. For T. boliviana, in light of the high mortality of the N1, insects were reared on different diets to detect if they could exploit haemolymphagy as a survival strategy (see Table I for details). Insects were divided into four groups according to their diet: (i) $100 \%$ of feedings on cockroach haemolymph (Cc); (ii) $100 \%$ of feedings with a choice between cockroach and mouse

TABLE I

Number of insects and percent mortality of Eratyrus ucronatus and Triatoma boliviana present at each instar, for all diet types

\begin{tabular}{|c|c|c|c|c|c|c|c|}
\hline & \multicolumn{2}{|c|}{ E. mucronatus } & \multicolumn{5}{|c|}{ T. boliviana } \\
\hline & Cockroach & Mouse & $\mathrm{Cc}$ & $\mathrm{CcChCc}$ & $\mathrm{Ch}$ & $\mathrm{MCc}$ & Mouse \\
\hline N1 & $37(65)$ & $29(41)$ & \multicolumn{2}{|c|}{179 (93) } & $44(91)$ & - & $95(67)$ \\
\hline N2 & $13(61)$ & $17(18)$ & $5(60)$ & $7(43)$ & $4(75)$ & $33(67)$ & $31(6)$ \\
\hline N3 & $5(60)$ & $14(7)$ & $2(50)$ & $4(25)$ & $1(100)$ & $11(73)$ & $29(0)$ \\
\hline N4 & $2(0)$ & $13(8)$ & $1(0)$ & $3(67)$ & 0 & $3(67)$ & $29(3)$ \\
\hline N5 & $2(50)$ & $12(58)$ & $1(100)$ & $1(0)$ & 0 & $1(0)$ & $28(18)$ \\
\hline Adults & $1 \hat{\sigma}^{\prime}$ & $5(4 \hat{\jmath}, 1 ㅇ)$ & 0 & $1 \hat{\jmath}$ & 0 & 19 & $23(8 \hat{\jmath}, 15+)$ \\
\hline
\end{tabular}

Cc (100\% ockroach); CcChCc (N1, N4 and N5 on cockroach and choice cockroach/mouse for N2 and N3); Ch (100\% choice mouse/cockroach); MCc (N1 on mouse, and then N2 to N5 on cockroach) and M (100\% mouse). 
(Ch); (iii) N1 on mouse, and then from N2 until death on cockroach (MCc); and finally (iv) N1 on cockroach, N2 and N3 with a choice of mouse or cockroach, and from $\mathrm{N} 4$ until death only on cockroach $(\mathrm{CcChCc})$. Finally, five N1 of $T$. infestans, $18 \mathrm{~N} 1$ of $P$. rufotuberculatus, $32 \mathrm{~N} 1$ and 15 adults of $R$. stali were also provided a cockroach diet under the conditions previously described.

Results were compared with those obtained for insects reared under the same conditions of temperature and humidity but feeding on mice throughout their life cycle (mouse diet, abbreviated: $\mathrm{M}$ ).

Feeding setup - A triatomine was placed in a small jar of $7 \mathrm{~cm}$ diameter and $8 \mathrm{~cm}$ height, closed with a piece of tulle held in place by a rubber band. A piece of paper folded into pleats was introduced vertically into the jar to link the bottom of the jar and the tulle and offer a vertical resting place for the insect. In the case of feeding on a cockroach, the cockroach (adult or N5, 5-8 cm long) was introduced into the jar with the triatomine. In the case of feeding on a mouse, the mouse was placed inside a thin wire mesh tube that did not injure the mouse but prevented movement (similar to the setup used in Klotz et al. 2009); the immobilised mouse was then placed on the tulle piece. The bug was able to feed by climbing on the paper piece and ingesting blood through the tulle. In the case of a choice in food source, both mouse and cockroach were offered to the triatomine.

Effect of cockroach diet on infected triatomines - As explained previously, E. mucronatus and T. boliviana in Bolivia have a very low infection index, with parasites being detected only by PCR. The hypothesis that a haemolymph diet could decrease the $T$. cruzi infection rate in triatomines was tested in both species by a small experiment: triatomines (one $P$ E. mucronatus, one $P$, five $\hat{\alpha}$ and three N5 of T. boliviana) were artificially infected with a strain of $T$. cruzi extracted from infected T. infestans specimens captured in Province of Murillo, La Paz Department. These experimentally infected triatomines were then provided a cockroach diet (twice a week, same conditions of rearing and feeding as described above), and the infection rate of the triatomines was obtained at 49 and 70 days by observation of the faeces (obtained by gently squeezing live triatomines, mixing the faeces with physiological serum and analysing the mixture using a light microscope to identify the presence of flagellates).

Ethics - The experiments were performed at the National Institute of Laboratories in Health (INLASA), which reports to the Health Ministry and operates according to the national law on the care and use of laboratory animals. Mice were obtained from the Rabies Vaccine Production Laboratory of INLASA's mouse husbandry lab. Particular attention was taken to ensure animal welfare in our experiments (use of one mouse to feed only one insect every two weeks; gentle immobilisation of the mouse during triatomine feeding). All the experiments were approved by the Institute.

\section{RESULTS}

Triatomines could ingest haemolymph from different physiological parts of the cockroach (ventral part, legs, head); the most frequent feeding location was the legs (Figure).

E. mucronatus - Of the $37 \mathrm{~N} 1$ in the experiment, only one specimen developed into an adult (Table I). The mortality rate was high in each instar (> 50\%). On a mouse diet, the mortality rate was also increased, especially for N1 and N5 (Table I), but it was significantly lower than the mortality rate of triatomines on a cockroach diet (Fisher Exact test: $\mathrm{p}=0.002$ ). Analysis of N1 mortality showed that the nymphal mortality occurred (i) before a successful feeding, (ii) before molting after feeding at least one time, or (iii) during molting. The greatest difference between diets was in the proportion of nymphs that fed and died before molting (Table II). Indeed, the latter was higher on a cockroach diet $(46 \%)$ than on a mouse $\operatorname{diet}(14 \%)$. This type of death occurred at an age that was not significantly different from the age of molting in both

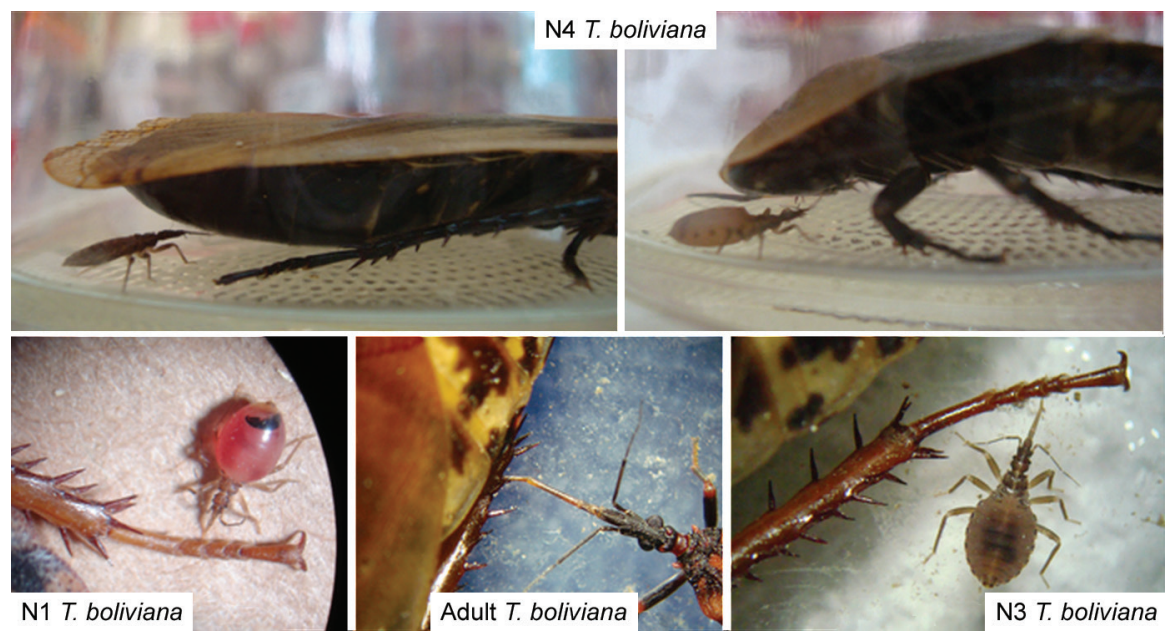

Triatoma boliviana feeding on cockroach haemolymph. They could ingest haemolymph from different parts of the cockroach (ventral part, legs, head), with the most frequent location being the legs. 
diets (Mann-Whitney U test comparing the lifetimes of N1 that molted and those that died before molting: cockroach diet: $\mathrm{W}=94, \mathrm{p}=0.50$; mouse diet: $\mathrm{W}=28, \mathrm{p}=$ 0.52 ). N1 that ate and died before molting had a significantly smaller weight than those that succeeded to molt on the cockroach diet (Mann-Whitney $\mathrm{U}$ test: $\mathrm{W}=53, \mathrm{p}$ $=0.016$ ). No difference was observed between these two groups on a mouse diet (Mann-Whitney U test: $\mathrm{W}=19.5$, $p=0.17)$. The day of the first meal did not differ between the cockroach and a mouse diets (Mann-Whitney U test: $\left.\mathrm{W}=77, \mathrm{~N}_{\mathrm{Cc}}=13, \mathrm{~N}_{\mathrm{M}}=18, \mathrm{p}=0.11\right)$.

Triatomines reared on cockroach needed a higher number of meals to molt, especially for N1, N2 and N3 (Table III). Comparing the maximum gain of weight per instar between the cockroach and mouse diets, the nymphal instars reared on cockroach tended to have a higher weight increase, except for N1, in which food intake was significantly lower on the cockroach diet (Table III). The age of molting tended to be higher on the cockroach diet (Table III).
Only one specimen reached the adult stage (male) on a cockroach diet. It lived 276 days, which is older than the median life expectancy of males on a mouse diet (134 days, $\max =265$ days, $\min =80$ days, 12 males observed). Its frequency of cockroach feeding was once per eight days, which is more frequently than was observed on a mouse diet (median feed frequency: 12 days, $\max =21$ days, $\min =10$ days, 12 males observed). Its median rate of weight increase per feeding was 1.1, which is similar to the rate observed for males on a mouse diet (median rate of $1.1, \max =3.5, \mathrm{~min}$ $=0.4,12$ males observed). To observe its fecundity, a female (fed on mouse) that had recently emerged was added; ten eggs were laid, from which two hatched and survived. The female died after two months.

T. boliviana - The proportion of nymphs reaching the adult stage was zero for insects rearing on the $\mathrm{Cc}$ or $\mathrm{Ch}$ diets and very low among those reared on the $\mathrm{CcChCc}$ (one male) or MCc diets (one female, Table I). In contrast, $24 \%$ of the N1 instars developed into adults on the mouse diet.

TABLE II

Eratyrus mucronatus and Triatoma boliviana N1 development on the different diets types

\begin{tabular}{|c|c|c|c|c|c|}
\hline & \multicolumn{2}{|c|}{ E. mucronatus (N1) } & \multicolumn{3}{|c|}{ T. boliviana $(\mathrm{N} 1)$} \\
\hline & Cockroach & Mouse & Cockroach & Choice & Mouse \\
\hline No eating & $5(14)$ & $4(14)$ & $106(59)$ & $24(55)$ & $63(66)$ \\
\hline Eating but no molt & $17(46)$ & $4(14)$ & $61(34)$ & $16(36)$ & $1(1)$ \\
\hline Eating, death during molting & $2(5)$ & $3(10)$ & - & - & - \\
\hline Eating and molt & $13(35)$ & $18(62)$ & $12(7)$ & $4(9)$ & $31(33)$ \\
\hline
\end{tabular}

Number (\%) of N1 that: (i) did not eat and died; (ii) ate and died before molting; (iii) ate, but died during molting; and (iv) ate and molted.

TABLE III

Development of nymphal instars of Eratyrus mucronatus

\begin{tabular}{|c|c|c|c|c|c|c|c|c|c|}
\hline & \multicolumn{3}{|c|}{ Feeding number } & \multicolumn{3}{|c|}{ Weight max / weight at molting } & \multicolumn{3}{|c|}{ Molting age (days) } \\
\hline & Cockroach & Mouse & W, p-value & Cockroach & Mouse & W, p-value & Cockroach & Mouse & $\mathrm{W}, \mathrm{p}$-value \\
\hline N1 & $\begin{array}{c}4.0 \\
(3.0-5.0)\end{array}$ & $\begin{array}{c}1.5 \\
(1.0-2.0)\end{array}$ & $229.5,<0.001$ & $\begin{array}{c}6.3 \\
(5.6-7.7)\end{array}$ & $\begin{array}{c}8.4 \\
(8.0-9.5)\end{array}$ & $46.5,<0.01$ & $\begin{array}{c}36 \\
(34-40)\end{array}$ & $\begin{array}{c}33 \\
(29-37)\end{array}$ & $164,0.06$ \\
\hline N2 & $\begin{array}{c}3.0 \\
(2.0-5.0)\end{array}$ & $\begin{array}{c}1.0 \\
(1.0-2.0)\end{array}$ & $61,0.01$ & $\begin{array}{c}6.9 \\
(6.4-7.0)\end{array}$ & $\begin{array}{c}4.6 \\
(3.7-4.8)\end{array}$ & $69,<0.001$ & $\begin{array}{c}35 \\
(35-42)\end{array}$ & $\begin{array}{c}26 \\
(24-28)\end{array}$ & $61,0.01$ \\
\hline N3 & $\begin{array}{c}4.0 \\
(4.0-4.0)\end{array}$ & $\begin{array}{c}2.0 \\
(1.0-2.0)\end{array}$ & $26,0.02$ & $\begin{array}{c}5.7 \\
(4.6-6.7)\end{array}$ & $\begin{array}{c}4.8 \\
(4.3-4.9)\end{array}$ & $14,0.93$ & $\begin{array}{c}42 \\
(38-45)\end{array}$ & $\begin{array}{c}28 \\
(25-33)\end{array}$ & $22.5,0.13$ \\
\hline N4 & $\begin{array}{c}3.5 \\
(2.8-4.3)\end{array}$ & $\begin{array}{c}2.0 \\
(2.0-2.0)\end{array}$ & $18,0.24$ & $\begin{array}{c}4.8 \\
(4.1-5.5)\end{array}$ & $\begin{array}{c}4.1 \\
(3.9-5.1)\end{array}$ & $11,0.92$ & $\begin{array}{c}51 \\
(50-51)\end{array}$ & $\begin{array}{c}31 \\
(28-36)\end{array}$ & $24,0.03$ \\
\hline N5 & $\begin{array}{l}7.0 \\
(-)\end{array}$ & $\begin{array}{c}6.0 \\
(5.0-6.0)\end{array}$ & $4,0.55$ & $\begin{array}{l}3.9 \\
(-)\end{array}$ & $\begin{array}{c}2.9 \\
(2.6-3.4)\end{array}$ & $5,0.33$ & $\begin{array}{l}99 \\
(-)\end{array}$ & $\begin{array}{c}60 \\
(49-66)\end{array}$ & $5,0.33$ \\
\hline
\end{tabular}

The number of feedings, maximum increase in weight (expressed as the maximum weight achieved by the nymph at instar $i$ divided by its weight just after molting into instar $i$ ) and molting age for each instar and for both a cockroach and a mouse diets are provided. All data are expressed in median values with interquartile ranges. The $\mathrm{W}$ and $\mathrm{p}$-value for the Mann-Whitney $\mathrm{U}$ test to compare data between the diets is provided. 
The N1 mortality rate was significantly lower for nymphs fed on mouse than on cockroach or having the choice between mice or cockroach feedings (Table I, respectively $67 \%, 93 \%$ and $91 \%$, Chi-squared test: $X^{2}$ $=34.4, \mathrm{p}<0.001$; Fisher Exact test: $\mathrm{p}<0.001)$. Triatomines from first nymphal instar died without feeding (while the possibility of feeding was given) or died before molting. No significant difference was found in the proportion of $\mathrm{N} 1$ that died without feeding between the three diets (Table II, Chi-squared test: $\mathrm{X}^{2}=2.1, \mathrm{p}=0.35$; Fisher Exact test: $p=0.34$ ). The proportion of nymphs that fed and died before molting was similar between the cockroach diet and choice diet; this proportion was higher than in the group fed the mouse diet (Chi-squared test: $\mathrm{X}^{2}=40.4, \mathrm{p}<0.001$; Fisher Exact test: $\mathrm{p}<0.001$ ).
The N1 age at the first meal intake did not differ between the mouse and a cockroach diets (Mann-Whitney U test: $\left.\mathrm{W}=130.5, \mathrm{~N}_{\mathrm{Cc}}=12, \mathrm{~N}_{\mathrm{M}}=27, \mathrm{p}=0.33\right)$.

The number of feedings and the maximum food intake for N1 instars were not significantly different between the three diets (Table IV, Kruskal-Wallis test: $\mathrm{X}^{2}$ $=5.7, \mathrm{p}=0.06$; and $\mathrm{X}^{2}=1.2, \mathrm{p}=0.57$, respectively). The time for molting was significantly higher for triatomines on the choice diet than for those on a mouse diet (Kruskal-Wallis test: $\mathrm{X}^{2}=8.8, \mathrm{p}=0.01$ followed by a Bonferroni multiple comparisons test). When N1 molted to N2, the weight of emerging nymphs reared on the cockroach and choice diets were statistically significantly lower than nymphs on the mouse diet (KruskalWallis test: $\mathrm{X}^{2}=13.8, \mathrm{p}=0.001$ followed by a Bon-

TABLE IV

Development of nymphal instars of Triatoma boliviana

\begin{tabular}{lllllll}
\hline Diet & $\mathrm{Cc}$ & $\mathrm{CcChCc}$ & $\mathrm{Ch}$ & $\mathrm{MCc}$ & $\mathrm{M}$ \\
\hline
\end{tabular}

Feeding number (Q1-Q3), Number of studied insects

\begin{tabular}{lccccc}
\hline N1 & $3.0(2.0-3.2), 12$ & $2.5(2.0-3.0), 4$ & - & $2.0(2.0-2.5), 31$ \\
N2 & $3.0(3.0-3.0), 2$ & $2.5(1.8-3.0), 4$ & $4.0(-), 1$ & $4.0(3.0-5.5), 11$ & $2.0(1.0-2.0), 29$ \\
N3 & $5.0(-), 1$ & $2.0(2.0-2.5), 3$ & - & $4.0(4.0-6.0), 3$ & $2.0(2.0-3.0), 29$ \\
N4 & $2.0(-), 1$ & $5.0(-), 1$ & - & $9.0(-), 1$ & $4.0(3.0-4.0), 28$ \\
N5 & - & $7.0(-), 1$ & - & $11(-), 1$ & $6.0(5.0-7.0), 23$
\end{tabular}

Weight max / weight at molting

\begin{tabular}{|c|c|c|c|c|c|}
\hline N1 & \multicolumn{2}{|c|}{$7.3(6.1-8.7), 12$} & $7.6(7.2-8.4), 4$ & - & $7.0(6.1-7.9), 31$ \\
\hline $\mathrm{N} 2$ & $6.6(6.6-6.6), 2$ & $7.1(6.9-7.2), 4$ & $8.8(-), 1$ & $4.8(4.1-6.4), 11$ & $5.8(5.0-7.3), 29$ \\
\hline N3 & $4.3(-), 1$ & $4.8(4.3-5.0), 3$ & - & $4.8(4.7-5.5), 3$ & $4.7(4.2-5.2), 29$ \\
\hline N4 & $6.5(-), 1$ & $4.2(-), 1$ & - & $6.9(-), 1$ & $3.9(3.5-4.2), 28$ \\
\hline N5 & - & $4.1(-), 1$ & - & $6.6(-), 1$ & $3.1(2.7-3.3), 23$ \\
\hline
\end{tabular}

Molting age (days)

\begin{tabular}{lccccc}
\hline N1 & \multicolumn{2}{c}{$42(37-43), 12$} & $56(52-58), 4$ & - & $35(34-41), 31$ \\
N2 & $49(44-55), 2$ & $31(30-33), 4$ & $28(-), 1$ & $62(49-70), 11$ & $28(28-32), 29$ \\
N3 & $60(-), 1$ & $31(30-38), 3$ & - & $50(45-68), 3$ & $34(31-35), 29$ \\
N4 & $73(-), 1$ & $84(-), 1$ & - & $90(-), 1$ & $45(39-46), 28$ \\
N5 & - & $98(-), 1$ & - & $140(-), 1$ & $70(64-83), 23$ \\
\hline
\end{tabular}

Weight $\mathrm{N}_{\mathrm{i}}$ at molting / Weight $\mathrm{N}_{\mathrm{i}-1}$ at molting

\begin{tabular}{lccccc}
\hline N1 & $3.1(2.9-3.4), 12$ & $2.4(2.0-2.8), 4$ & - & $4.5(3.5-5.0), 31$ \\
N2 & $3.6(2.6-4.5), 2$ & $4.0(3.8-4.3), 4$ & $5.3(-), 1$ & $1.7(1.6-2.4), 11$ & $3.8(3.0-4.3), 29$ \\
N3 & $2.2(-), 1$ & $2.6(2.3-3.0), 3$ & - & $2.4(1.9-2.8), 3$ & $3.0(2.9-3.6), 29$ \\
N4 & $1.6(-), 1$ & $1.5(-), 1$ & - & $2.9(-), 1$ & $2.5(2.4-2.6), 28$ \\
N5 & - & $1.9(-), 1$ & - & $1.9(-), 1$ & $1.9(1.6-2.0), 23$ \\
\hline
\end{tabular}

The number of feedings, maximum increase in weight (expressed as the maximum weight achieved by the nymph at instar $i$ divided by its weight just after molting into instar $i$ ), molting age, and weight increase from one instar to the next one (expressed as the weight of $\mathrm{N}_{i}$ at molting divided by the weight of $\mathrm{N}_{\mathrm{i}-1}$ at molting) are given for each instar and for all diet type. All data are expressed as median values with interquartile ranges; the number of studied insects is provided in italic. Cc (100\% cockroach), CcChCc (N1, N4 and N5 on cockroach and choice cockroach /mouse for N2 and N3), Ch (100\% choice mouse/cockroach), MCc (N1 on mouse, and then N2 to N5 on cockroach) and M (100\% mouse). 
ferroni multiple comparison test). Even if low survival rates prevented the statistically significant determination of the impact of the diets on the development, a trend was clearly observable: the cockroach diet tended to increase the maximum food intake and number of feedings required for molting, resulting in an increased molting period (almost twice that of mouse-diet fed triatomines) and a smaller weight at emergence. When choice between feeding on a mouse or cockroach was provided, nymphs $\mathrm{N} 2$ and N3 tended to prefer to feed on a mouse (24 feedings observed from six N2 and three N3: 17 feedings on mouse and seven on cockroach).

Two nymphs reached adulthood: one female (MCc diet) and one male $(\mathrm{CcChCc}$ diet). The weight of these adults after molting was lower than the median weight of insects fed only on mouse [female: $0.0803 \mathrm{~g}$, median and interquartiles of the weight on the mouse diet: $0.1429 \mathrm{~g}(0.1269-0.1578)$; male: $0.0807 \mathrm{~g}, 0.1182 \mathrm{~g}$ (0.1048-0.1345)]. Compared with insects reared on the mouse diet, adults feeding on cockroach seemed to have a higher, but not more frequent, food intake (Table V). The lifespan of this female was lower than the median lifespan of the insects fed on mouse; in contrast, the lifespan of the male was higher (Table V). The female on the MCc diet was only fed on cockroach and reared in pair with a male fed on mouse. This female did not lay eggs. The male on the $\mathrm{CcChCc}$ diet was also only fed cockroach. It was reared with three females on the mouse diet. After their emergence, two of these females (A and B) were offered only cockroaches, and one was offered only mice $(\mathrm{C}$, Table V). For females A and B, one did not lay any eggs; the other female laid 13 eggs, of which six N1 hatched and survived (median hatching time: 38 days). The female $\mathrm{C}$ laid 28 eggs, of which only one N1 hatched and survived (hatching time: 39 days).
T. infestans, P. rufotuberculatus and R. stali - As few insects and instars were included from these three species, these results must be considered preliminary observations of other species under the same conditions. Concerning $T$. infestans, none of the N1 fed on cockroach. Mortality occurred at the age of 67-86 days and 16-22 contacts with the cockroach. All N1 of P. rufotuberculatus died without feeding at a median age of 12 days old after two to three contacts with the cockroach. Only one nymph succeeded once in feeding on a small amount of cockroach's haemolymph, but it died 10 days later. For the $32 \mathrm{~N} 1$ of $R$. stali, none fed on cockroach. They died between eight-47 days old (median: 13), after one-12 contacts with the cockroach (median: two). None of the adults of $R$. stali fed on the cockroach. Males survived the starvation for somewhat longer than females (58 versus 40 days, respectively; Mann-Whitney U test: $\mathrm{N}_{0}^{\hat{\gamma}}=7, \mathrm{~N}$ + $\left.=8, \mathrm{~W}=10.5, \mathrm{p}=0.048\right)$ and had a higher number of contacts with the cockroach (median number of contacts for males: 15 , and for females: 10).

Effect of cockroach diet on infected triatomines Moving parasites were detected by microscopy in all the triatomines of both species at 49 and 70 days (triatomines fed $\sim$ once a week on cockroach haemolymph).

\section{DISCUSSION}

Haemolymphagy could be a good strategy for triatomines to survive in a wild environment offering few vertebrate hosts. Some species have already been reported to be able to exploit haemolymph to survive (Alves et al. 2011, Pontes et al. 2011) or even to use it as a principal food source (Sandoval et al. 2010, 2013). Cockroaches are present in a variety of habitats and could represent a source of haemolymph with relatively easy access. Moreover, they are the principal food source of the Belminus

TABLE V

Comparison of feeding behaviour and fecundity among adults of Triatoma boliviana under cockroach and mouse diets

\begin{tabular}{|c|c|c|c|c|}
\hline & $\begin{array}{l}\text { Lifetime } \\
\text { (days) }\end{array}$ & $\begin{array}{c}\text { Time between feeding } \\
\text { (days) }\end{array}$ & $\begin{array}{l}\text { Ratio of weigh } \\
\text { after feeding }\end{array}$ & $\begin{array}{l}\text { Number of hatched eggs } \\
\text { (total number) }\end{array}$ \\
\hline Female $(\mathrm{MCc}) n=1$ & 81 & $4(3-7), a=13$ & $2.0(1.9-2.1), a=13$ & $0(0)$ \\
\hline Females (M) $n=14$ & $235(184-286)$ & $6(4-7), a=512$ & $1.0(1.0-1.1), a=512$ & $732(1448)$ \\
\hline MW U-test & - & $\mathrm{W}=2969, \mathrm{p}=0.50$ & $\mathrm{~W}=5, \mathrm{p}<0.001$ & \\
\hline Male $(\mathrm{CcChCc}) n=1$ & 417 & $5(3-10), a=59$ & $1.2(1.0-1.3), a=59$ & - \\
\hline Males (M) $n=8$ & $140(123-156)$ & $7(4-7), a=168$ & $0.9(0.9-1.0), a=158$ & - \\
\hline MW U-test & - & $\mathrm{W}=4914.5, \mathrm{p}=0.92$ & $W=1635, p<0.001$ & \\
\hline Female A (Cc) & 161 & $9(3-13)$ & $1.4(1.0-1.5)$ & $6(13)$ \\
\hline Female B (Cc) & 145 & $5(3-9)$ & $0.9(0.8-0.9)$ & $0(0)$ \\
\hline Female C (M) & 280 & $7(4-10)$ & $1.6(1.5-1.7)$ & $1(28)$ \\
\hline
\end{tabular}

Lifetime (days), time between two feedings (days), increase of weight after feeding and the number of hatched eggs are provided. All data are expressed as median values with interquartile ranges. The p-value for the Mann-Whitney U test to compare data between the diets is provided. $n$ : the number of observed triatomines; $a$ : is the number of feeding observations. The feeding diet of study insects is also provided ( $\mathrm{MCc}, \mathrm{M}, \mathrm{CcChCc}$, see Materials and Methods section 2.1 for more information). 
ferroae triatomine species (Sandoval et al. 2010, 2013). Nevertheless, the results presented here suggest that haemolymphagy using adult/N5 cockroaches as a food source is uncommon in the studied species.

Although the results for T. infestans, P. rufotuberculatus and $R$. stali must be considered as preliminary and studied further, data from these species can be discussed here to orient future research. T. infestans N1 died rather than feed on cockroaches. Their resistance to starvation was very high compared with the other species (67-86 days). Some wild foci have been identified (Noireau et al. 2005b, Bacigalupo et al. 2010, Buitrago et al. 2010, Waleckx et al. 2012), but they generally live in large numbers inside or around the human dwellings where vertebrate hosts are continuously present. Recently, Alves et al. (2011) found that nymphal instars of T. infestans are able to practice intrasubfamily haemolymphagy and cleptohaematophagy. In the case of a lack of vertebrate hosts, this species might be more inclined to practice cleptohaematophagy/intrasubfamily haemolymphagy than to feed on haemolymph from other arthropods such as cockroaches. P. rufotuberculatus refused also to feed on cockroach under our conditions. Just one first instar fed once on haemolymph, but it was not sufficient to survive. Their resistance to starvation was low under our conditions (12 days). In Bolivia, this species lives in human dwellings in association with guinea pigs reared by inhabitants, which are also a stable food source (Depickère et al. 2011). Few data are available regarding their natural food sources in the wild; however, they are reported to feed on Dasypodidae, Procyonidae and bats (Carcavallo et al. 1998). In the genus Panstrongylus, P. megistus (Carcavallo et al. 1998 - without detail) and P. geniculatus (Garrouste 2009 - fed on Lepidoptera haemolymph) are reported to practice haemolymphagy. Additional studies are required to understand the importance and type (intraspecies, intrasubfamily or extrasubfamily) of haemolymphagy for $P$. rufotuberculatus. Finally, $R$. stali is an Amazonian species living in palm trees and potentially feeding on birds and mammals (Carcavallo et al. 1998). In the Pantanal region of Brazil, R. stali is reported to live in arboreal nests of coatis (de Lima et al. 2015). In Bolivia, they are also found in the peridomiciles of human dwellings, especially in association with hens, and some domestic infestations have been reported (Matias et al. 2003, Justi et al. 2010, Martínez et al. 2012). They were found together with various species of cockroaches (Depickère, pers. com). Nevertheless, under our conditions, neither the N1, nor the adults, fed on cockroaches. Their resistance to starvation was higher than that of $P$. rufotuberculatus but lower than that of T. infestans. In the genus Rhodnius, $R$. prolixus was revealed to practice intraspecies cleptohaematophagy (Marinkelle 1965); haemolymphagy was not reported.

For the $37 \mathrm{~N} 1$ of E. mucronatus, only one survived to the adult stage. This result suggests that survival in this species is compromised by a diet of cockroach haemolymph alone. On the other hand, it also suggests that haemolymph provides sufficient nutriment to allow development into a fertile adult. Compared to a mouse diet, the cockroach diet seemed to increase (1) the mor- tality at each instar, (2) the number of feedings needed to molt, (3) the volume of maximum food intake, and (4) the time needed to molt. This species lives in Bolivia in peridomiciles, where they were found together with cockroaches (Depickère et al. 2012). In the wild, E. mucronatus lives in large, hollow trees; adults feed on porcupines (Coendou prehensilis), and the youngest instars have been observed feeding on the haemolymph of the large arachnids (Amblypygi) that inhabit hollow trees (Miles et al. 1981, Carcavallo et al. 1998, Gaunt \& Miles 2000). Our results suggest that this species could utilise the presence of cockroaches in their environment to facilitate survival. Haemolymph is probably not their principal host, but exploitation of this food source may be possible. Haemolymph facilitates survival at each instar, molting, and fertility.

T. boliviana is also able to exploit haemolymph from cockroaches to survive. Nevertheless, they have more challenges in exploiting this food source than $E$. $m u$ cronatus. Indeed, their mortality rate was very high, especially for N1. With just a cockroach diet, none of the N1 developed into adult in this experiment. The effects of the cockroach diet were similar to those observed in E. mucronatus, including an increase in the mortality per instar, number of feedings needed to molt, volume of food intake, and time needed to molt. The provision of a choice between a mouse and a cockroach did not seem to improve development, especially for N1 instars, when compared with a cockroach diet. This result was not found for $\mathrm{N} 2$ (CcChCc diet), for which biological development was closer to that of the N2 reared on a mouse diet. This could suggest a difficulty for the N1 nymphs in finding the mouse that was at the top of the container. On the contrary, N2 utilise both food sources and were stronger and had superior motility. Although they were able to feed on haemolymph, our data suggest that the $\mathrm{N} 2$ and N3 nymphal instars preferred feeding on mice.

Generally, haemolymphagy is predominately cited as a survival practice for the youngest instars. We hypothesised similar behaviour in T. boliviana, in which N1 mortality was very high when reared under laboratory conditions with mice as a food source (Durán et al. 2014). When the cockroach and mouse diets were compared, there was no difference in the number of $\mathrm{N} 1$ that died without feeding or the age at first meal. Hence, the attraction towards the cockroach was similar to that towards the mouse. The highest mortality in N1 instars was observed in cases in which nymphs fed and died before molting; this was observed in both $T$. boliviana and E. mucronatus species. These nymphs were characterised by a low median weight increase. Two hypotheses can be put forward: (i) access to the cockroach haemolymph presents an additional challenge and/or (ii) the haemolymph nutriments are not an optimal food source for triatomines. Some observations supported the first hypothesis; in the experiments, the cockroaches used as a food source were adults or N5. They were of greater size $(5-8 \mathrm{~cm})$ than the triatomine N1 instars $(3$ $\mathrm{mm})$. On a few occasions, the N1 individuals were found dead, squashed by the cockroach. Therefore, the adult cockroach might represent a danger for the youngest tri- 
atomine instars, and this could decrease the success of feeding on haemolymph, even if the triatomine saliva is known to have a paralysing effect on the host (Alves et al. 2011). The youngest cockroach instars may be better prey. On the other hand, some other observations support the second hypothesis: the youngest instars needed to feed at a greater quantity and frequency to molt. Even as adults, they fed more often or had a higher volume of intake on the cockroach diet when compared with the mouse diet. This suggests that haemolymph may be digested more quickly than blood, and so represented a challenge in developing to the next instar.

Interestingly, the lifespan of the single male of $E$. mucronatus and the single male of $T$. boliviana that completed their development was relatively long. No statistical data can be expressed using only data from two individuals, but, for example, adults of $B$. ferroae have been suggested to have a longer lifespan on a cockroach diet relative to a mouse diet (Sandoval et al. 2013). Previous studies have suggested that the blood diet is deficient in several essential factors, such as vitamin B (Lehane 2005), and the digestion of haemoglobin results in the production of large amounts of haeme, a potentially cytotoxic molecule that can exert biological damage (Graça-Souza et al. 2006, Donohue et al. 2009). On the other hand, the female $T$. boliviana died relatively quickly; that may simply be an unfortunate case or it may suggest that the import of blood is more important for females. Further studies are needed to investigate these issues.

Finally, as explained previously, E. mucronatus and T. boliviana in Bolivia have a very low infection index, $0 \%$ in T. boliviana (microscopy) and $0 \%$ (microscopy) and $19 \%$ (PCR) in E. mucronatus (Noireau et al. 1995, Depickère et al. 2012). The hypothesis that a diet based on haemolymph (cockroach haemolymph, in our case) could reduce triatomine infection was not supported by our results, with parasites being still easily observed in the faeces of the experimental insects by microscopy after 70 days. Further experiments should be carried out to test the effect on the T. cruzi strain of a haemolymph food source.

In conclusion, T. boliviana and E. mucronatus are able to feed on the haemolymph of cockroaches, which could be a timely food source to improve the survival rates. The results of this study represent a first step in increasing knowledge of the effect of diets on the biological cycle of triatomines and suggest additional questions. A field study of triatomine meal sources is strongly recommended to better characterise their alimentary habits and to observe the real rate of feeding on cockroaches or other arthropods in the field. The degree of cleptohaematophagy, intraspecific haemolymphagy and phytophagy should also be investigated.

\section{ACKNOWLEDGEMENTS}

To $F$ Brenière and $F$ Lardeux, for their logistical support, and E Martinez, for his contribution in the conception of this study.

\section{REFERENCES}

Alves CL, Araujo RN, Gontijo NF, Pereira MH. Importance and physiological effects of hemolymphagy in triatomines (Hemiptera: Reduviidae). J Med Entomol. 2011; 48(2): 372-81.
Bacigalupo A, Torres-Pérez F, Segovia V, García A, Correa JP, Moreno L, et al. Sylvatic foci of the Chagas disease vector Triatoma infestans in Chile: description of a new focus and challenges for control programs. Mem Inst Oswaldo Cruz. 2010; 105(5): 633-41.

Brumpt E. Importance du cannibalisme et de la coprophagie chez les Réduvidés hématophages (Rhodnius, Triatoma) pour la conservation des Trypanosomes pathogènes en dehors de l'hôte vertébré. Bull Soc Pathol Exot. 1914; 7: 702-5.

Buitrago R, Waleckx E, Bosseno MF, Zoveda F, Vidaurre P, Salas $\mathrm{R}$, et al. First report of widespread wild populations of Triatoma infestans (Reduviidae, Triatominae) in the valleys of La Paz, Bolivia. Am J Trop Med Hyg. 2010; 82(4): 574-9.

Carcavallo RU, Girón IG, Jurberg J, Lent H. Atlas of Chagas' disease vectors in the Americas. 1st ed. Rio de Janeiro: Fiocruz; 1998.

Cardozo-de-Almeida M, Neves SC, Almeida CE, Lima NR, Oliveira ML, Santos-Mallet JR, et al. Biology of Triatoma carcavalloi Jurberg, Rocha \& Lent, 1998 under laboratory conditions. Rev Soc Bras Med Trop. 2014; 47(3): 307-12.

de Lima JS, Rocha FL, Alves FM, Lorosa ES, Jansen AM, Mourão GM. Infestation of arboreal nests of coats by triatomine species, vectors of Trypanosoma cruzi, in a large Neotropical wetland. J Vector Ecol. 2015; 40(2): 379-85.

Depickère S, Durán P, López R, Chávez T. Presence of intradomicile colonies of the triatomine bug Panstrongylus rufotuberculatus in Muñecas, La Paz, Bolivia. Acta Trop. 2011; 117(2): 97-100.

Depickère S, Durán P, López R, Martinez E, Chávez T. After five years of chemical control: colonies of the triatomine Eratyrus mucronatus are still present in Bolivia. Acta Trop. 2012; 123(3): 234-8.

Díaz-Albiter HM, Ferreira TN, Costa SG, Rivas GB, Gumiel M, Cavalcante DR, et al. Everybody loves sugar: first report of plant feeding in triatomines. Parasit Vectors. 2016; 9: 114.

Donohue KV, Khalil SM, Sonenshine DE, Roe RM. Heme-binding storage proteins in the Chelicerata. J Insect Physiol. 2009; 55(4): 287-96.

Durán P, Siñani E, Depickère S. Biological cycle and preliminary data on vectorial competence of Triatoma boliviana in laboratory conditions. Acta Trop. 2014; 140: 124-9.

Emmanuelle-Machado P, Koerich LB, Joukoski DB, Carvahlo-Pinto CJ, Grisard EC, Steindel M. Biology of Triatoma klugi Carcavallo, Jurberg, Lent \& Galvão 2001 (Heteroptera: Reduviidae) under laboratory conditions: effects of distinct blood sources and susceptibility to Trypanosoma cruzi and Trypanosoma rangeli. Mem Inst Oswaldo Cruz. 2002; 97(4): 583-7.

Freitas SP, Lorosa ES, Rodrigues DC, Freitas AL, Gonçalves TC. Feeding patterns of Triatoma pseudomaculata in the state of Ceara, Brazil. Rev Saude Publica. 2005; 39(1): 27-32.

Garrouste R. First observation in natura of entomophagy of Panstrongylus geniculatus (Latreille 1811), vector of Chagas disease (Hemiptera: Reduviidae). Ann Soc Entomol Fr. 2009; 45(3): 302-4.

Gaunt M, Miles M. The ecotopes and evolution of triatomine bugs (Triatominae) and their associated trypanosomes. Mem Inst Oswaldo Cruz. 2000; 95(4): 557-65.

Graça-Souza AV, Maya-Monteiro C, Paiva-Silva GO, Braz GR, Paes MC, Sorgine MH, et al. Adaptations against heme toxicity in blood-feeding arthropods. Insect Biochem Mol Biol. 2006; 36(4): 322-35.

Justi SA, Noireau F, Cortez MR, Monteiro FA. Infestation of peridomestic Attalae phalerata palms by Rhodnius stali, a vector of Trypanosoma cruzi in the Alto Beni, Bolivia. Trop Med Int Health. 2010; 15(6): 727-32. 
Justi SA, Russo CA, Mallet JR, Obara MT, Galvão C. Molecular phylogeny of Triatomini (Hemiptera: Reduviidae: Triatominae). Parasit Vectors. 2014; 7: 149.

Klotz SA, Dorn PL, Klotz JH, Pinnas JL, Weirauch C, Kurtz JR, et al. Feeding behavior of triatomines from the southwestern United States: an update on potential risk for transmission of Chagas disease. Acta Trop. 2009; 111(2): 114-8.

Lehane M. The biology of blood-sucking in insects. 2nd ed. Cambridge: Cambridge University Press; 2005.

Lent H, Wygodzinsky P. Revision of the Triatominae (Hemiptera, Reduviidae), and their significance as vectors of Chagas' disease. Bull Am Museum Nat Hist. 1979; 163: 123-520.

Lorosa ES, Jurberg J, Souza AL, Vinhae MC, Nunes IM. Hemolinfa de Dictyoptera na manutenção do ciclo biológico silvestre de Triatoma rubrovaria (Blanchard, 1843) e Triatoma circummaculata (Stål, 1859) (Hemiptera, Reduviidae, Triatominae). Entomol Vectores. 2000; 7(3): 287-96.

Marinkelle CJ. Direct transmission of Trypanosoma cruzi between individuals of Rhodnius prolixus Stål. Rev Biol Trop. 1965; 13(1): $55-8$.

Martínez E, Chávez T, Sossa D, Aranda R, Vargas B, Vidaurre P. Triatoma boliviana sp. n. (Hemiptera: Reduviidae: Triatominae) from Sub Andean valleys of La Paz - Bolivia, related to Triatoma nigromaculata Stål, 1859. Rev Cuad Hosp Clin. 2007; 52(1): 9-16.

Martínez E, Durán P, López R, Chávez T, Aliaga C, Lardeux F, et al. Trypanosoma cruzi I transmitido por Rhodnius stali en un foco emergente del trópico de La Paz. In: Workshop Epidemiología molecular y evolucion de enfermedades infecciosas en América Latina; 2012 Apr 25-27. La Paz: UMSA; 2012. p. 53.

Matias A, de la Riva J, Martinez E, Tórrez M, Dujardin JP. Domiciliation process of Rhodnius stali (Hemiptera: Reduviidae) in Alto Beni, La Paz, Bolivia. Trop Med Int Health. 2003; 8(3): 264-8.

Miles MA, de Souza AA, Póvoa M. Chagas' disease in the Amazon basin III. Ecotopes of ten triatomine bug species (Hemiptera: Reduviidae) from the vicinity of Belém, Pará state, Brazil. J Med Entomol. 1981; 18(4): 266-78.

Noireau F, Bosseno MF, Carrasco R, Telleria J, Vargas F, Camacho $\mathrm{C}$, et al. Sylvatic triatomines (Hemiptera: Reduviidae) in Bolivia: trends toward domesticity and possible infection with Trypanosoma cruzi (Kinetoplastida: Trypanosomatidae). J Med Entomol. 1995; 32(5): 594-8.

Noireau F, Carbajal-de-la-Fuente AL, Lopes CM, Diotaiuti L. Some considerations about the ecology of Triatominae. An Acad Bras Cienc. 2005a; 77(3): 431-6.

Noireau F, Cortez MG, Monteiro FA, Jansen AM, Torrico F. Can wild Triatoma infestans foci in Bolivia jeopardize Chagas disease control efforts? Trends Parasitol. 2005b; 21(1): 7-10.

Phillips NR. Experimental studies on the quantitative transmission of Trypanosoma cruzi: aspects of the rearing maintenance and testing of vector material, and of the origin and course of infection in the vector. Ann Trop Med Parasitol. 1960; 54: 397-414.

Piñero DF, Carcavallo RU, Fernandez E. Canibalismo y transmisión directa de $T$. cruzi entre ninfas de Rhodnius prolixus. Chagas. 1988; 5: 18-22.
Pontes GB, Noireau F, Lorenzo MG. Behavioral evidence of an ectoparasitic interaction between Triatoma pseudomaculata Corrêa \& Espínola (Heteroptera: Reduviidae) and Periplaneta americana (L.) (Blattodea: Blattidae). Neotrop Entomol. 2011; 40(6): 708-10.

Ruas-Neto AL, Corseuil E, Cavalleri A. Development of rupestrian triatomines (Hemiptera: Reduviidae: Triatominae) following haemolymphagy on blaberids (Blattodea: Blaberidae) in Rio Grande do Sul state, Brazil. Entomol Vectores. 2001; 8: 205-16.

Ryckman RE. Recent observations of cannibalism in Triatoma (Hemiptera: Reduviidae). J Parasitol. 1951; 37(51): 433-4.

Salvatella R, Calegari L, Puime A, Basmadjian Y, Rosa R, Guerrero J, et al. Feeding patterns of Triatoma rubrovaria (Blanchard, 1843) (Hemiptera, Triatominae) in peridomestic habitats, in a rural area of Uruguay. Rev Inst Med Trop Sao Paulo. 1994; 36(4): 311-20.

Salvatella R, Calegari L. T. circummaculata (Stål, 1859) (Hemiptera, Triatominae) y su alimentación sobre B. dubia (Serville, 1837) (Blataria, Blaberinae). In: X Congreso Latinoamericano de Parasitología; 1991 Nov 17-22; Montevideo. p. 210.

Sandoval CM, Duarte R, Gutíerrez R, Rocha DS, Angulo VM, Esteban L, et al. Feeding sources and natural infection of Belminus herreri (Hemiptera, Reduviidae, Triatominae) from dwellings in Cesar, Colombia. Mem Inst Oswaldo Cruz. 2004; 99(2): 137-40.

Sandoval CM, Joya MI, Gutierez R, Angulo VM. Cleptohaematophagy of the Triatomine bug Belminus herreri. Med Vet Entomol. 2000; 14(1): 100-1.

Sandoval CM, Medone P, Nieves EE, Jaimes DA, Ortiz N, Rabinovich JE. Demographic fitness of Belminus ferroae (Hemiptera : Triatominae) on three different hosts under laboratory conditions. Mem Inst Oswaldo Cruz. 2013; 108(7): 854-64.

Sandoval CM, Ortiz N, Jaimes D, Lorosa E, Galvão C, Rodriguez $\mathrm{O}$, et al. Feeding behaviour of Belminus ferroae (Hemiptera: Reduviidae), a predaceous Triatominae colonizing rural houses in Norte de Santander, Colombia. Med Vet Entomol. 2010; 24(2): 124-31.

Silva MB, Jurberg J, Barbosa HS, Rocha DS, Carcavallo RU, Galvão C. Comparative morphology of eggs and nymphs of Triatoma vandae Carcavallo, Jurberg, Rocha, Galvão, Noireau \& Lent, 2002 and Triatoma williami Galvão, Souza \& Lima, 1965. Mem Inst Oswaldo Cruz. 2005; 100(6): 549-61.

Telleria J, Tibayrenc M, editors. American trypanosomiasis Chagas disease - one hundred years of research. 1st ed. London: Elsevier; 2010.

Vezzani D, Schweigmann NJ, Pietrokovsky SM, Wisnivesky-Colli C. Characterization of Triatoma guasayana biotopes in a hardwood forest of Santiago del Estero, Argentina. Mem Inst Oswaldo Cruz. 2001; 96(4): 459-66.

Waleckx E, Depickère S, Salas R, Aliaga C, Monje M, Calle H, et al. New discoveries of sylvatic Triatoma infestans (Hemiptera: Reduviidae) throughout the Bolivian Chaco. Am J Trop Med Hyg. 2012; 86(3): 455-8.

WHO - World Health Organization. Chagas disease (American trypanosomiasis): fact sheet 340. Geneva: WHO; 2010.

Zeledón R, Cordero M, Marroquín R, Lorosa ES. Life cycle of Triatoma ryckmani (Hemiptera: Reduviidae) in the laboratory, feeding patterns in nature and experimental infection with Trypanosoma cruzi. Mem Inst Oswaldo Cruz. 2010; 105(1): 99-102. 